\title{
Awareness of Tuberculosis in University Biotechnology
}

\section{Students}

\section{Imran Qadir M* and Faryal Batool \\ Institute of Molecular Biology \& Biotechnology, Bahauddin Zakariya University, Multan, Pakistan}

*Corresponding author: Muhammad Imran Qadir, Institute of Molecular Biology \& Biotechnology, Bahauddin Zakariya University, Multan, Pakistan, Email: mrimranqadir@hotmail.com

\section{Short Communication}

Volume 4 Issue 1

Received Date: January 12, 2019

Published Date: March 01, 2019

DOI: $10.23880 /$ oajmb-16000140

\section{Abstract \\ Tuberculosis is considered to be one of the highly contagious and lethal infectious diseases and can cause millions of deaths every year. It is caused by Mycobacterium tuberculosis. Tuberculosis affect the lungs and if not treated can lead to the death of the infected person. The basic purpose of this study was to determine the awareness of biotechnology students about this lethal disease tuberculosis. We had designed a questionnaire to evaluate the awareness of university biotechnology students based on their family history and their course studies. It is concluded from this study that most of the postgraduate students are aware of etiology, prevalence, mode of transmission and methods of treatment for tuberculosis disease.}

Keywords: Tuberculosis; Mycobacterium Tuberculosis; Awareness Survey

\section{Introduction}

Tuberculosis is considered to be remain one of the highly contagious and lethal infectious diseases and can cause millions of deaths every year [1]. Tuberculosis is an infectious disease caused by Mycobacterium tuberculosis. In this disease lungs of the patient are affected. Sometimes other body parts can also be affected through bloodstream for example kidneys and spine [2]. TB patient if not treated can also be died. It can spread from diseased to normal person through air. Women \& men of childbearing age in developing countries are more susceptible to this disease [3]. TB is the main reason of death of the persons with HIV. The basic purpose of this study was to determine the awareness of biotechnology students about this lethal disease tuberculosis [4].

\section{Methodology}

We had designed a questionnaire (Table 1) containing 15 questions to promote awareness of the deadly disease Tuberculosis in university Biotechnology students. This questionnaire was filled by 37 students of biotechnology of Bahauddin Zakariya University, Multan. Only post graduate students were selected to fill this questionnaire and B.S Biotechnology students were not allowed. 


\begin{tabular}{|c|c|c|c|}
\hline \multicolumn{2}{|r|}{ Tuberculosis is a } & Yes & No \\
\hline 1. & Viral disease & & \\
\hline 2. & Bacterial disease & & \\
\hline 3. & Fungal disease & & \\
\hline 4. & Genetic disease & & \\
\hline 5. & Metabolic disease & & \\
\hline \multicolumn{4}{|c|}{ Ever suffered from Tuberculosis } \\
\hline 6. & You & & \\
\hline 7. & Your family & & \\
\hline 8. & Your relative & & \\
\hline 9. & Your neighbor & & \\
\hline & Your friend & & \\
\hline \multicolumn{4}{|c|}{ Tuberculosis is transmitted by } \\
\hline 11. & Contacts or blood transfusion & & \\
\hline & From parents to offspring & & \\
\hline \multicolumn{4}{|c|}{ Tuberculosis may be treated by } \\
\hline 13. & Medicines & & \\
\hline 14. & Surgery & & \\
\hline 15. & Do not worry, it is easily curable & & \\
\hline
\end{tabular}

Table 1: Questionnaire to evaluate awareness about etiology of Tuberculosis.

\section{Results \& Discussion}

Awareness about etiology of Tuberculosis in post graduate students is in Table 2 . According to $17 \%$ males and 3\% female's tuberculosis is a viral disease while total $5 \%$ students mentioned tuberculosis is a viral disease. $100 \%$ male and $90 \%$ female and $92 \%$ of total students agreed tuberculosis is a bacterial disease. $100 \%$ male, female and the total number of students agreed that TB is not a fungal disease while $0 \%$ male and $3 \%$ female and total number of students considered it a genetic disease. According to $0 \%$ male students, $13 \%$ female and $11 \%$ total students agreed that TB is a metabolic disease.

\begin{tabular}{|l|c|c|c|c|c|c|}
\hline \multirow{2}{*}{ Tuberculosis is a } & \multicolumn{2}{|c|}{ Male } & \multicolumn{2}{c|}{ Female } & \multicolumn{2}{c|}{ Total } \\
\cline { 2 - 7 } & Yes & No & Yes & No & Yes & No \\
\hline 1. Viral disease & $17 \%$ & $83 \%$ & $3 \%$ & $97 \%$ & $5 \%$ & $95 \%$ \\
\hline $\begin{array}{l}\text { 2. Bacterial } \\
\text { disease }\end{array}$ & $100 \%$ & $0 \%$ & $90 \%$ & $10 \%$ & $92 \%$ & $8 \%$ \\
\hline $\begin{array}{l}\text { 3. Fungal } \\
\text { disease }\end{array}$ & $0 \%$ & $100 \%$ & $0 \%$ & $100 \%$ & $0 \%$ & $100 \%$ \\
\hline $\begin{array}{l}\text { 4. Genetic } \\
\text { disease }\end{array}$ & $0 \%$ & $100 \%$ & $3 \%$ & $97 \%$ & $3 \%$ & $97 \%$ \\
\hline $\begin{array}{l}\text { 5. Metabolic } \\
\text { disease }\end{array}$ & $0 \%$ & $100 \%$ & $13 \%$ & $87 \%$ & $11 \%$ & $89 \%$ \\
\hline
\end{tabular}

Table 2: Awareness about etiology of Tuberculosis. Views of Postgraduate Biology Students
Prevalence about tuberculosis in post graduate students is in Table 3. $0 \%$ males, $3 \%$ females and total students were suffered from TB. While, any of the family members of $50 \%$ males, $19 \%$ females and $24 \%$ total number students and 83\% males, 29\% females and 35\% total students reported that any one of their relative was suffered by this disease. Neighbors of $83 \%$ males, $32 \%$ females and $38 \%$ total students and friends of $33 \%$ males, $10 \%$ females and 14\% total students suffered from this disease.

\begin{tabular}{|l|c|c|c|c|c|c|}
\hline \multirow{2}{*}{$\begin{array}{c}\text { Ever suffered from } \\
\text { Tuberculosis }\end{array}$} & \multicolumn{2}{|c|}{ Male } & \multicolumn{2}{c|}{ Female } & \multicolumn{2}{c|}{ Total } \\
\cline { 2 - 7 } Yes & No & Yes & No & Yes & No \\
\hline 1. You & $0 \%$ & $100 \%$ & $3 \%$ & $97 \%$ & $3 \%$ & $97 \%$ \\
\hline 2. Your Family & $50 \%$ & $50 \%$ & $19 \%$ & $81 \%$ & $24 \%$ & $76 \%$ \\
\hline 3. Your Relative & $83 \%$ & $17 \%$ & $29 \%$ & $71 \%$ & $35 \%$ & $65 \%$ \\
\hline 4. Your Neighbor & $83 \%$ & $17 \%$ & $32 \%$ & $68 \%$ & $38 \%$ & $62 \%$ \\
\hline 5. Your Friend & $33 \%$ & $67 \%$ & $10 \%$ & $90 \%$ & $14 \%$ & $86 \%$ \\
\hline
\end{tabular}

Table 3: Questionnaire to evaluate views about prevalence of Tuberculosis.

Evaluation of views of postgraduate students about transmission of Tuberculosis is in Table 4. According to $33 \%$ males, $58 \%$ females and $49 \%$ total students, $\mathrm{Tb}$ is transmitted by any type of contact or blood transfusion while, according $0 \%$ males, $23 \%$ females and $20 \%$ total students this disease is transmitted from parents to offspring.

\begin{tabular}{|l|c|c|c|c|c|c|}
\hline \multirow{2}{*}{$\begin{array}{l}\text { Tuberculosis is } \\
\text { transmitted by }\end{array}$} & \multicolumn{2}{|c|}{ Male } & \multicolumn{2}{|c|}{ Female } & \multicolumn{2}{|c|}{ Total } \\
\cline { 2 - 7 } & Yes & No & Yes & No & Yes & No \\
\hline $\begin{array}{l}\text { 1. Contact or blood } \\
\text { transfusion }\end{array}$ & $33 \%$ & $67 \%$ & $58 \%$ & $42 \%$ & $49 \%$ & $51 \%$ \\
\hline $\begin{array}{l}\text { 2. Parents to } \\
\text { offspring }\end{array}$ & $0 \%$ & $100 \%$ & $23 \%$ & $77 \%$ & $20 \%$ & $80 \%$ \\
\hline
\end{tabular}

Table 4: Questionnaire to evaluate views about transmission of Tuberculosis.

For methods of treatment for tuberculosis disease, we have considered three option for survey, medicine, surgery and 'Don't worry it is easily curable'. Third option actually means no medication is required, it can be treated itself. Evaluation of how Tuberculosis can be treated is in Table 5. According to $100 \%$ males, $94 \%$ females and $96 \%$ total students; TB can be treated by medicines which is an easy method for treating tuberculosis. While $100 \%$ of males, females and total students agreed that TB cannot be treated by surgery. 


\section{Open Access Journal of Microbiology \& Biotechnology}

\begin{tabular}{|cc|c|c|c|c|c|c|}
\hline \multirow{2}{*}{$\begin{array}{c}\text { Mode of Treatment } \\
\text { for Tuberculosis }\end{array}$} & \multicolumn{2}{|c|}{ Male } & \multicolumn{2}{c|}{ Female } & \multicolumn{2}{c|}{ Total } \\
\cline { 2 - 7 } & Yes & No & Yes & No & Yes & No \\
\hline 1. & Medicine & $100 \%$ & $0 \%$ & $94 \%$ & $6 \%$ & $95 \%$ & $5 \%$ \\
\hline 2. & Surgery & $0 \%$ & $100 \%$ & $0 \%$ & $100 \%$ & $0 \%$ & $100 \%$ \\
\hline
\end{tabular}

Table 5: Questionnaire to evaluate views about Hope for Tuberculosis.

\section{Conclusion}

This study was actually planned to evaluate either university students are aware of Tuberculosis disease (etiology, prevalence, mode of transmission and methods for treatment) based on their previous knowledge from their course studies and their family history. Main purpose of this study was to decide either these university students need to be further educated about this disease, so that they can practice the safety measures. It is concluded from this study that most of the postgraduate students are aware of tuberculosis disease. They are familiar of proper etiology, prevalence, mode of transmission and methods for treatment of this disease. This survey was conducted to find out that university students have enough knowledge regarding this disease or not based on their family history and the course study. Few population based surveys have also been published already about symptoms of tuberculosis [5] and a survey prevalence of this disease in Viet Nam [6].

This study was actually designed to evaluate either university students are aware of Tuberculosis disease (etiology, prevalence, mode of transmission and methods for treatment) based on their previous knowledge from their course studies and their family history. Main purpose of this study was to decide either these university students need to be further educated about this disease, so that they can practice the safety measures. This study was actually designed to evaluate either university students are aware of Tuberculosis disease (etiology, prevalence, mode of transmission and methods for treatment) based on their previous knowledge from their course studies and their family history. Main purpose of this study was to decide either these university students need to be further educated about this disease, so that they can practice the safety measures. This study was actually designed to evaluate either university students are aware of Tuberculosis disease (etiology, prevalence, mode of transmission and methods for treatment) based on their previous knowledge from their course studies and their family history. Main purpose of this study was to decide either these university students need to be further educated about this disease, so that they can practice the safety measures. This study was actually designed to evaluate either university students are aware of Tuberculosis disease (etiology, prevalence, mode of transmission and methods for treatment) based on their previous knowledge from their course studies and their family history. Main purpose of this study was to decide either these university students need to be further educated about this disease, so that they can practice the safety measures.

\section{References}

1. Sepkowitz KA (1996) How contagious is tuberculosis?. Clinical Infectious Diseases 23(5): 954962.

2. Sepkowitz KA (1994) Tuberculosis and the health care worker: a historical perspective. Annals of internal medicine 120(1): 71-79.

3. Behr MA, Waters WR (2014) Is tuberculosis a lymphatic disease with a pulmonary portal?. Lancet infect diseases 14(3): 250-255.

4. Bass Jr JB, Farer LS, Hopewell PC, O'Brien R, Jacobs R, et al. (1994) Treatment of tuberculosis and tuberculosis infection in adults and children. American Thoracic Society and The Centers for Disease Control and Prevention. Am J Respir Crit Care Med 149(5): 1359-1374.

5. Miller LG, Asch SM, Yu EI, Knowles L, Gelberg L, et al. (2000) A population-based survey of tuberculosis symptoms: how atypical are atypical presentations?. Clinical infectious diseases 30(2): 293-299.

6. Hoa NB, Sy DN, Nhung NV, Tiemersma EW, Borgdorff MW, et al. (2010) National survey of tuberculosis prevalence in Viet Nam. Bull World Health Organ 88(4): 273-280.
Imran Qadir M and Faryal Batool. Awareness of Tuberculosis in University Biotechnology Students. J Microbiol Biotechnol, 2019, 4(1): 000140.
Copyright $(\subset$ Imran Qadir M and Faryal Batool. 